only 2.7 per cent of research and development in private industry proceeds in Scotland, and that the Department of Scientific and Industrial Research is responsible for 81 per cent of research in shipbuilding and engineering. Some 58 per cent of engineering students in the University of Glasgow found work out of Scotland; for Edinburgh the figure was 69 per cent, and for Aberdeen 64 per cent.

Lady Tweedsmuir, who supported the Ordinance, asked for more information about university expenditure on research and on teaching. At Aberdeen in 1959-60 there were 91 full-time and 24 part-time postgraduate research students, compared with 77 and 22, respectively, in 1954-55. Research Fellows were very few, and the Scottish nniversities asked of this Ordinance that they should have the same facilities as English universities enjoyed to attract research workers. Mr. G. M. Thomson, who also asked for further information, questioned whether the pattern of professorships in the Scottish universities is appropriate to modern noeds. $\mathrm{He}$ also stressed the importance of adequate finance, and suggested that more provision is required for the training of posigraduate students, betser facilities for those with a technological qualification to qualify for research awards and a free flow of information between the universities, Parliament and the interested public. Sir Myer Galpern challenged some of these views, and suggested that much information is already available; he claimed that the Scottish universities already produce research students of very high calibre. The Joint Under-Secretary of State for Scotland, Mr. Niall Macpherson, intervened to point out that the Government regards the matter as one for the universities alone, and stressed its desire not to infringe their independence in matters of acedemic policy. Miss M. Herbison, referring to applications for grants for special researches from the Department of Scientific and Industrial Research, pointed out that of 25 in 1959-60 from Scottish universities, 13 came from the Royal College of Science and Technology, Glasgow. Dr. A. E. Thompson also supported this plea for more co-operation between the universities and the technical colleges, and for much greater facilities for exchange of staff between universities and other research institutions.

Another debate, on an adjournment, was opened by Mr. T. F. Peart, who raised specifically the responsibilities of the Minister for Science and his relation to the Ministry of Education. After stressing the importance of the contribution which British scientific man-power should make to Colonial development, Mr. Peart urged the full implementation of the De La Wart report on higher education in agriculture, stressed the need for adequate teaching of science in the teacher-training colleges and for a good supply of graduates in science from the universities who would take a teacher's diploma. He said he is concerned about the teaching of science in girls' schools and the supply of science teachers and equipment for such schools, and asked for a major debate on the place of science in our economy and the functions and responsibilities of the Minister for Science and the Minister of Education. The Parliamentary Secretary to the Minister of Education, $\mathrm{Mr}$. $\mathrm{K}$. Thompson; replying for the Government, welcomed the debate, but claimed that much is already being done to relieve the shortage of science teachers. He said that a very large proportion of the expansion of the teacher-training colleges would be in the numbers of teachers qualified to teach science at various levels in the schools. He agreed that we could also use part of this expanded output to provide an introduction to science in the primary as well as secondary modern and grammar schools. In the main, there are, he said, three levels of teacher-training for science courses in the training colleges: the ordinary curriculum; one providing for a main study of a science subject; and the advanced specialist course in a science subject. The number of teacher-training college students in mathematics and science has increased from 600 in 1956-57 to more than 1,100 in 1959-60, and the net increase in mathematics and science graduates in 1959 was 612 . Plans for university expansion should provide an 80 per cent increase in science graduates in the period up to 1960 .

\title{
ADULT EDUCATION
}

A HEARTWARMING tribute to the work of local enthusiasts for continued education has been paid by the Joint Committee for Adult Education of Queen's University of Belfast. In its twenty-eighth annual report it states that "it is eommonplace, when adult education is discussed to-day, to lament the crusades of the founding fathers. It is even commoner to deprecate the decline of local responsibility and initiative, and the abdication of sustained and particular studies, in favour of the armchair and the printed or televised magazine. The experience of the Joint Committee and its officers is in contrast to all this".

These words, to the University Council for Adult Education, are in general borne out by the reports of other extra-mural departments*.

In spite of problems of finance, the total number of courses shows a slight increase, from 4,612 in $1957-58$ to 4,741 in $1958-59$. The volume of work

* Universities Council for Adult Education. Report on the Year 1958-1959. Pp. 34. (Bristol : W. E. Salt, Honorary Secretary and Treasurer, The University, 1960.) has remained almost stationary for the past three years, but these figures mask the continued decline of tutorial classes, a trend which has gone on steadily for several years, as is shown by the figures :

$$
\begin{array}{ccccc}
1954-55 & 1955-56 & 1956-57 & 1957-58 & 1958-59 \\
983 & 959 & 950 & 904 & 851
\end{array}
$$

Its decline must cause disquiet, but it is encouraging that tutorial classes organized in collaboration with the Workers' Educational Association have shown a less-sharp fall (from 619 to 600) than others (from 285 to 241 ).

Television has been regarded as a serious rival to adult education, and blamed for the decline in tutorial classes. It is therefore interesting to find the University College of North Wales, Bangor, postulating the possibility that the coming of television may prove an advantage to adult education in so far as its better programmes tend to encourage "viewers to seek further enlightenment on the topics treated in them while the inferior programmes drive the more intelligent citizen to seek better pastures". 
The number of residential courses shows a 12 per cent increase over the 1957-58 figure, although, as last year's total was smaller than the $1955-56$ and 1956-57 figures, the gain in part represents a recovery in lost ground. The increase is entirely in the shorter residential courses, that is, those of not more than seven days in length. At Cambridge, where Madingley Hall has been used to the full extent of its availability, the most interesting and promising developments are thought to be those in residential courses.

Table 1. Trenos in Adulit Education, 1953-59

\begin{tabular}{|c|c|c|c|c|c|c|}
\hline & $\begin{array}{c}1953- \\
54\end{array}$ & $\begin{array}{c}1954- \\
55\end{array}$ & $\begin{array}{c}1955- \\
56\end{array}$ & $\begin{array}{c}1956- \\
57\end{array}$ & $\begin{array}{c}1957- \\
58\end{array}$ & $\begin{array}{c}1958- \\
59\end{array}$ \\
\hline Religion & 180 & 211 & 222 & 252 & 251 & 270 \\
\hline $\begin{array}{l}\text { Biology } \\
\text { Language and }\end{array}$ & 245 & 258 & 252 & 274 & 274 & 294 \\
\hline literature & 636 & 685 & 675 & 681 & 689 & 719 \\
\hline Visual arts & & & & 370 & 383 & 421 \\
\hline
\end{tabular}

Table 1 confirms certain trends which have become discernible in adult education during the past few years. The reasons for these changes are not clear, but speculation indicates that the hydrogen bomb and affairs in Africa throw up moral problems that turn the minds of some men and women to a deeper study of the religious beliefs which have been a formative force in Western civilization. The Dead Sea scrolls combine the excitement of archæological discovery with the higher criticism. The contraction of the world prompts the serious and sympathetic study of religions that become less strange the more they are understood. It is possible that courses with a religious content satisfy some of the interests that previously found an outlet in the study of philosophy and of international affairs. The upward trend of courses in the visual arts has become clearly dis. cernible.
There has been a marked improvement during the past few years in much of the accommodation in which extra-mural work takes place. Gradually, it is being recognized that adult education needs, and deserves, accommodation of its own, and the number of adult education centres steadily increases, some provided by universities, some by local education authorities, and some by voluntary organizations. The University of Leeds has established non-residential centres for extra-mural work at Bradford and Middlesbrough, each under the oversight of a member of the Department's teaching staff acting as warden. The University of Liverpool has made the Royal Institution available as a centre for extra-mural courses.

The tendency towards meeting the needs of special groups is discernible in the class programme of extra-mural departments, as well as in residential courses. The Edinburgh report contains an apposite comment on this development: "There is a considerable demand for classes of a semi-vocational nature but in this field extra-mural educational aetivities are limited to work for which the university is particularly suited. Classes in Agricultural Law, Income Tax, Estate Duty and Company Administration, Industrial Law, Advanced Management, Effective Reading and Programming for Digital Computers indicate a change in the pattern of extramural work but they should be regarded as a widening of the scope of such work rather than a change of emphasis". Oxford has embarked on a scheme, with support from the Leverhulme Trust, for the preparation of relevant and conveniently accessible teaching material--hitherto lacking-in trade union education. Special studies are being undertaken in three industries in Oxford's area-coal mining, engineering, and road passenger transport-in the hope that the resulting material will be suitable for publication for use by classes throughout Great Britain .

\section{THE MELLON INSTITUTE}

$\mathrm{T}$

WE annual report on research, by the chairman, Mr. M. B. Ridgway, to the Board of Trustees of the Mellon Institute for the year ended February 29 , besides a review of activities and of independent research during the year, of the research services and research for public welfare, includes a list of research personnel and of publications of Mellon Institute members during the year*. Fundamental research now represents about 20 per cent of the Institute's research effort, and two new fundamental research groups, one in continuum mechanics and viscoelasticity and the other in theoretical chemistry, began activity during the year. Among the continuing groups, expansion was chiefly in polymer science, metal physics and radiation, while in the applied research groups those in the science of metals also expanded. The independent research siaff increased from 56 to 77 , and 16 groups are now engaged in fundamental research. At the end of the year there were 42 industrially sponsored fellowships and projects in applied science with a staff of 210 . Research services employed 26 professional scientists,

* Mellon Institute Research 1959-1960: The Annual Report of the Chairman, Patthew $\mathbf{R}$. Ridgway, to the Board of Trustees of the (Pittsburgh: Mellon Institute, 1960.) and exclusive of part-time employees the total staff of the Institute was 536 ; expenditure for fundamental and applied research during the year was $5,781,000$ dollars.

In studies on enzymatic hydroxylation a third hydroxylating co-factor has now been isolated from cultures of Mycobacterium 607 which reverses the inhibition of hydroxylation caused by tetracycline and also that caused by 2:4-dinitrophenol. In inorganic chemistry osmium and ruthenium complexes were characterized and investigations started on the co-ordination complexes of rhenium, iridium and platinum, while many basic compounds have been prepared in polycrystalline form by homogeneous hydrolysis in the range $170-300^{\circ} \mathrm{C}$. Investigations of the structure and properties of macromolecules continued, and the stress-strain curves for a wide variety of cross-linked polymers revealed substantial agreement with the theoretically predicted form when measurements were made under conditions permitting reasonable approach to equilibrium. In metal physics an improved method was developed for evaluating the lattice spacings of gold-based and silver-based alloys, and the study of strain-induced transformation in silver-zinc alloys in the $\beta$-phase range was 